\title{
Organizing Solidarity Initiatives: A socio-spatial conceptualization of resistance
}

\author{
Maria Daskalaki \\ Kingston University, Kingston Business School \\ Kingston-Upon-Thames, KT2 7LB \\ m.daskalaki@kingston.ac.uk
}

George Kokkinidis

University of Leicester, School of Business

Leicester, LE1 7RH

gak7@le.ac.uk

Paper accepted for publication in Organization Studies.

Special Issue on 'Resistance, resisting, and resisters in and around organizations'

Corresponding Author:

Maria Daskalaki, Kingston Business School, Kingston University, Kingston Upon

Thames, Surrey, KT2 7LB, UK. Email: M.Daskalaki@kingston.ac.uk 


\title{
Organizing Solidarity Initiatives: A socio-spatial conceptualization of resistance
}

\begin{abstract}
This paper offers a spatial conceptualization of resistance by focusing on the practices through which solidarity initiatives constitute new resistance socio-spatialities. We discuss two solidarity initiatives in Greece, WCNA and Vio.Me SI, and explore how they institute distinctive local and translocal organizational practices that make the production of new forms of resistance possible. In particular, we adopt a productive and transformative view of resistance and first, identify three local practices of organizing solidarity initiatives namely, the organization of general assembly meetings, the constitution of resistance laboratories and the (re)articulation of sociospatial relations in local sites. Then, we turn to flows, movements, and translocal resistance formations and examine the role of solidarity mobilizations, the material and symbolic co-production of resources and members' mobility in the production of resistance. We conclude that new resistance socio-spatialities become constitutive of a broader reconfiguration of political agencies, a creative process that challenges existing relations and invites alternative ways of working and organizing.
\end{abstract}

Keywords: Mobility, resistance, socio-spatial relations, space, solidarity, translocal

\section{Introduction}

Back in 2010, John Holloway in Crack Capitalism proposed that urban mobilizations, expressed through a range of collective actions, could constitute a challenge to the dominant economic and political order. In recent years, following the 2008 economic meltdown, people across the world have protested in the streets and occupied squares to show their discontent, demanding not only their right to employment and fair pay but also 'Democracia Real Ya!' that could replace established institutions and structures of alleged democratic representation (Hardt \& Negri, 2012). The urban insurgencies in the cities of Athens, Istanbul, London and Paris, the Arab uprisings, 
the Occupy movements and the Indignados in Spain, provided collective spaces where dissent, opposition and resistance to neoliberal hegemony were manifested (Dhaliwal, 2012; Graeber, 2013; Maeckelbergh, 2009). Prior studies focused on a repertoire of 'action contexts', what Haug (2013, p. 706) called the 'backstage' of these insurgencies, and stressed that urban mobilizations, by instituting a new sociospatial order, could bring about lasting social formations and social change (Featherstone, 2008; Hardt \& Negri, 2012; Harvey, 2012; Swyngedouw, 2013). In other words, if the dominant order is legitimized through socio-spatial relations, and the current economic and political regimes are normalized through particular modes of spacing and ordering (Foucault, 1984, 1986) then it is also through socio-spatial reconfiguration that new modes of resistance could emerge.

This paper contributes to recent spatial conceptualizations of resistance (Courpasson, Dany, \& Delbridge, 2017; Courpasson \& Vallas, 2016; Fernández, Marti, \& Farchi, 2016) and examines it as a creative process, with a particular emphasis on local and translocal socio-spatial resistance practices 'through which political horizons are made, unmade and remade' (Vasudevan, 2015, p. 319). Responding to the call for a critical engagement with geographies of resistance (Courpasson et al., 2017), we explore resistance, not as a situated struggle against sovereign power and authority, but as a transformative force that is distributed across spaces and times. This force enacts different capacities and forms of political agency, transcends 'the existing “limits" of social possibility' (Bloom, 2016: 3) and replaces existing socialities with different ways of being in the world. 
By focusing on the power dynamics of spatial organizing (Kronberger \& Clegg, 2004), our study affirms that resistance, as a social practice, should be studied in relation to the places where things happen (Courpasson et al., 2017; Courpasson \& Vallas, 2016; Juris, 2008; Polletta, 1999). Yet, resisting places are not only actual, existing settings (Courpasson et al., 2017) or 'transitory dwelling places' (Shortt, 2015), but also 'autonomous, borderless spaces' generated by various intensities and flows (Hardt \& Negri, 2001). These flows enact resistances that 'run along dispersed, centripetal lines' (Hardy, 2016, p.104), and become something 'other' than a direct opposition or confrontation. Our conceptualization of resistance, following this, considers pre-constituted subjects who institute resistance practices within fixed and pre-defined spaces and crucially, emphasizes the distributed and fluid socio-spatial configurations, which produce transformative resistance socio-spatialities; resistance subjects and spaces that are 'always in motion' (Hannam, Sheller, \& Urry, 2006, p. 14). This conceptualization allows the study of resistance in relation to the local and translocal practices through which resisters consolidate and diffuse experience, resources and knowledge across spaces and times.

The paper is structured as follows. First, we discuss the interplay between fixity and mobility in relation to solidarity initiatives and resistance. Then we present the two solidarity initiatives and the methodology of this study, followed by the empirical findings section, which is structured in two parts. In the first part, we discuss the organizing practices of the two solidarity initiatives as these take place at the local level and we examine three key practices that, as we argue, create temporary fixities in space-time. These practices include the organization of general assembly meetings, the co-constitution of resistance laboratories and the (re)articulation of socio-spatial 
relations in local sites. We then identify three translocal practices of the solidarity initiatives namely, the organization and participation in solidarity mobilizations, the material and symbolic co-production of resources and finally, members' mobility schemes. We argue that these two sets of practices allow the initiatives to establish bridges across spatial scales in order to consolidate and diffuse resources, experiences and knowledge for the co-production of new forms of resistance and post-capitalist alternatives.

\section{Fixity-mobility and resistance: The constitution of solidarity initiatives}

Undoubtedly, studying resistance in relation to socio-spatial relations is not new. Various studies on social movements have already focused on the spatial dimensions of anti-capitalist struggles and resistance (Harvey 2012; Juris, 2008; Polleta, 1999; Stavrides, 2010). In the organization studies literature, in particular, an emerging literature on space/place ${ }^{1}$, through a spatial understanding of resistance, contributes to the study of political engagement, collective identities and meaning-creation at workplaces (Courpasson et al., 2017; Munro \& Jordan, 2013; Shortt, 2015). Crucially, acknowledging the 'mobile turn' in the study of space (Cresswell, 2006; Jensen, 2009; Thrift, 2008; Urry, 2007), several organization studies scholars have already challenged the idea of space as something fixed and static. Instead, they have proposed that mobility is a crucial component of contemporary organizational experiences that institutes complex modes of social engagement (Daskalaki, 2014; Jeanes, Loacker, Śliwa, \& Weiskopf, 2015; Maréchal, Linstead, \& Munro, 2011). Building upon this work, this article proposes that resistance spaces are produced by a spectrum of continuous performances, where transient socio-spatialities are constantly formed and transformed through the continuous interplay of fixities and mobilities. 
Mobility - the physical, temporal, economic and symbolic-imaginary movement of people, resources, ideas, images and information - cannot be performed without the existence of temporary spatial, infrastructural and institutional 'moorings' (Adey, 2010; Baerenholdt, 2013; Cresswell, 2006; Massey, 2005; Thrift, 2008; Jensen, 2011; Urry, 2007). Mobility and fixity therefore are inherently linked; one cannot exist without the other and they 'should not be seen as opposites, but as mutually constitutive conditions that intermingle in nuanced ways in the everyday lives of individuals' (McMorran, 2015, p. 83; see also Rogaly, 2015). Accordingly, we suggest that resistance spaces are part of an extensive system of fixed-mobile sociospatial entanglements, which constitute and are constituted by what Gustafson (2001) calls 'roots and routes'. This mobility-fixity interplay is achieved through the continuous process of (un-)forming and re-forming constellations of singularities that are re-constituted by differential flows of people, signs, and resources (Adey, Bissell, Hannam, Merriman, \& Sheller, 2014; Anderson, Kearnes, McFarlane, \& Swanton, 2012; DeLanda, 2006; McCann \& Ward, 2011)². As we argue, the study of the fixitymobility interplay allows for a conceptualization of resistance as a multitude of crossings through which new socio-spatialities are formed and transformed. Hence, rather than looking at spaces of resistance as static and disconnected, we highlight the flows and connectivities of actors across spaces and times. These flows and connectivities constitute and are constituted by socio-spatial solidarity relations what we refer to as solidarity initiatives - which do not result in isolated incidents of resistance, but signal the insurgence of a milieu of resistances through which the material, cultural as well as the individual and collective worlds meet. In other words, solidarity functions as the bridge that connects those autonomous and affective spaces 
that strive to construct alternatives to the alienation incited by neoliberalism and the indifference of state bureaucratic culture (Herzfeld, 1992; see also Rakopoulos, 2016; Rozakou, 2016).

This study explores solidarity initiatives (hereafter SIs) as self-organized, heterogeneous resistance formations, which defy capitalist enclosures and constantly transform the socio-spatial arrangements through and in which they are organized. We will show that SIs are socio-spatial configurations which, through instituting a range of local and translocal organizing practices, can enact alternative organizational forms. Without underestimating the importance of place-based politics, conceptualizing socio-spatial relations of resistance and solidarity in those mobile terms, shifts our attention to 'the ability of powerful bodies to draw distant others within close reach or construct the close-at-hand at a distance' (Allen, 2011, p. 283), and invites an understanding of resistance as constituted through re-appropriating control over the conditions of production and reproduction of socio-spatial relations. This process describes what Lefebvre (2009) calls 'autogestion'; a geographical project of the ways we can resist homogenization, and thus produce differential spaces at a variety of scales (Brenner \& Elden, 2009). 'Autogestion' is not a fixed condition, but an opening toward the possible that must continually be enacted (Lefebvre 2009).

Following this, we turn to the creative, constitutive and transformational potentialities of resistance formations and identify the specific local and translocal practices through which SIs resist the established relations and reconfigure the ways they organize, relate and ultimately, connect and resist through space. To unveil these 
practices with which SIs engage, we focus on the interplay of fixity-mobility and analyze how it becomes constitutive of socio-spatial relations with new resistance potentialities. We focus on the anti-capitalist movement in Greece and particularly, the organizing practices of two SIs, the Worker Cooperatives Network of Athens (WCNA) and Vio.Me Solidarity Initiative (Vio.Me.SI), described in detail in the section that follows.

\section{Research Context and Methodology}

Empirical Context: We begin this section by providing a brief account of the context in which the solidarity initiatives included in this study emerged and evolved. Since the beginning of the economic crisis, consecutive Greek governments have engineered a series of neoliberal reforms, implemented under the close supervision of the so-called Troika (European Commission, European Central Bank and International Monetary Fund). These reforms have resulted in a drastic deterioration of living standards: Pensioners have lost around a third of their income, wages in the private sector were cut by $13 \%$ and more than $20 \%$ in the public sector (Christopoulou \& Monastiriotis, 2016). The neoliberal reforms have also led to an unprecedented rise in unemployment rates (from $7.7 \%$ in 2008 to $24.3 \%$ in 2016), with official rates of youth unemployment at 51.9\% (Trading Economics, 2016). The welfare state in Greece has historically been very weak, and the family often substitutes the welfare state (Papadopoulos, 2006). After the crisis and the implementation of the austerity policies, the provision of social protection including benefits, health and childcare were cut significantly (by 22 per cent in 2013 only) as the need for those became greater than ever before (Matsaganis, 2013). Therefore, along with austerity cuts to cover budget deficits, the withdrawal of public services 
intensifies pressures on households; precarious low-income workers, family firm owners, single parents, people living on benefits, marginal groups, migrants and women find themselves excluded from any form of bearable urban livelihoods.

Responding to this, communities have started organizing 'from below' in an attempt to counteract the impact of harsh austerity. Successive mass protests erupted all over Greece forming an impressive anti-austerity campaign (Diani \& Kousis, 2014). At the same time, similar anti-austerity protests were organized in various cities around the world, leading scholars to argue for the emergence of a new global wave of protests (Della Porta \& Mattoni, 2014). However, despite similar anti-austerity frames and common repertoires of action, these protests evolved differently (Kanellopoulos, Kostopoulos, Papanikolopoulos \& Rongas, 2017). In Greece, like in other European countries, pre-existing networks and resistance movements helped in strengthening and sustaining anti-austerity mobilizations (Flesher Fominaya, 2015). Yet, in the Greek case, special attention has been paid on the role of new social actors: either individuals entering the politics of protest for the first time (Rudig \& Karyotis, 2013), or new social categories like young unemployed or precarious workers (Vogiatzoglou, 2015). Political and economic legitimation crises challenged established interpretive frameworks of meaning, as people withdrew their commitment to the social order and started creating alternative spaces in search of new ways of organizing life.

These spaces, along with the Greek Indignados movement in 2011, marked collective efforts to institute prefigurative social formations and provided alternatives to corrupted institutional structures, privatization of public spaces, collapse of the health care system and social services. These alternatives, guided by autonomy, solidarity and responsibility (Parker, Cheney, Fournier, \& Land, 2014), include occupied 
(public) spaces (Daskalaki, 2014; Daskalaki, in press), workers' collectives and cooperatives (Kokkinidis, 2015; Varkarolis, 2012), Local Exchange Trade Systems (Gritzas \& Kavoulakos, 2016), social clinics and pharmacies, and a variety of SIs (Rakopoulos, 2016). SIs address issues of social reproduction and respond to the affected communities' basic needs for food, clothing and health care (Arampatzi, 2016).

However, as we will argue, SIs also create the conditions for challenging neoliberal structures and the dominant economic order through transformative socio-spatial organizing practices. I particular, we focus on two key initiatives in Greece that have witnessed considerable expansion in the past few years, WCNA and Vio.Me.SI. The main criteria for selecting these two initiatives include their autonomy from political parties and financial institutions, their bottom-up mobilization, their common objectives, and their systematic presence in various political and economic activities. Moreover, these two SIs bring together several grassroots organizations, coconstituting a large part of the unfolding resistance landscape in Greece. Although both initiatives have commonalities in terms of values and objectives (for example, autonomy, cooperation and egalitarian structures), they are also characterized by distinctive organizing practices. For example, unlike WCNA that has an easily identifiable membership, Vio.Me.SI has a loose structure, including numerous members around Greece (with strong presence through local 'branches' in the cities of Athens, Heraklion, Patra and Larissa) and abroad (e.g. Argentina, France, Turkey and Italy).

WCNA was established in 2012 and currently includes three cooperative coffee shops, two Alternative and Solidarity Trade cooperatives and a cooperative bookshop. 
In addition, two cooperative coffee shops also participate in the initiative under the status of the 'observer' (see Figure 1). The second case, Vio.Me.SI, is a solidarity movement that was created in support of Vio.Me, a privately owned large production scale factory located in Thessaloniki. It is part of a metallurgy industrial group that went bankrupt in 2011. Vio.Me is the first incident of such a large production unit being undertaken by its own employees in the last few years in Europe and, according to the workers of Vio.Me, their initiative could encourage other similar projects to emerge in areas of Greece where industrial units are closing down. The occupied factory of Vio.Me, which re-started production under workers' control in February 2013, currently has twenty-five members and, similarly to the cooperatives in the WCNA case, is run by an anti-hierarchical logic, a rotation-based job allocation, egalitarian remuneration schemes and direct democratic participation. Vio.Me.SI was established immediately after the factory was recuperated and gradually expanded across and beyond Greece (Vogiatzoglou, 2015). As Figure 1 shows, Vio.Me.SI includes among others, a range of political and activist groups, workers' unions, a network of European and Mediterranean recuperated enterprises and workers' cooperatives, occupied spaces such as Scholio and other SIs including the WCNA. Vio.Me.SI also enjoys the support of individual people and has established an initiative called 'Solidarity Supporter' that currently registers over 1,000 members who commit to receiving a certain number of products from the factory (equivalent to a membership fee of three euros a month) in solidarity with the workers' struggles. Solidarity supporters have the right to participate in Vio.Me workers' assembly meetings, including the decision-making process through an advisory vote.

Insert Figure 1 about here 
Data Collection: While our involvement and participation in these initiatives is ongoing, the findings that we discuss in this paper are based on research conducted from July 2012 to July 2016. This research was based on participant observations conducted before and after the interviews with members of WCNA and Vio.Me.SI and was part of our activist involvement with the two SIs and the wider resistance movement in Greece. As Pain (2003, p. 652) argues, activism exists on a continuum and is embedded in all our activities as academics, '[it] can become a generative locus of new ways of thinking about the world and being in the world'. Despite an invitation from social geographers to engage more with academic/activist methodologies (Pain, 2003; Routledge, 1996; Ruddick, 2003), academic endeavors and activism remain quite distinctive and separate pursuits in the field of organization studies. We feel that research on alternative organizing and resistance requires 'a sharp refocusing of interest in activism as an explicit strategy and outcome of research and vice versa' (Pain, 2003, p. 652). This approach clearly poses challenges in the ways we perform our identities as academics/researchers and activists and relate with wider political subjectivities within and beyond the alternative organizations that we study/participate (Chatterton, Hodkinson, \& Pickerill, 2010).

Trying to maintain reflexive activist practice, that is, "working critically and progressively within academia, whether resisting wider external structures such as neoliberalism, or our own internal assumptions and values' (Maxey, 2004, p. 168; see also Maxey, 1999), we were constantly switching between our two roles. As activists, we actively participated and contributed to various meetings, events, following the flows of knowledge, people and relationships across different organizational spaces. 
As members of Vio.Me.SI ourselves, we joined three general assembly meetings and two festivals (Resistance Festival, Athens, 2014; CommonsFest, Athens 2015). We were also active members of two workshops held at Micropolis (a self-organized space in Thessaloniki), which were attended, besides the Vio.Me.SI, by other international self-organization initiatives and solidarity movements (Table 1).

Insert Table 1 about here

As academics and researchers, we participated as observers in a general assembly meeting of the WCNA in July 2014 (these meetings take place once a month). During this meeting, representatives from each cooperative group of the WCNA were present and the discussion turned around their political manifesto and future directions. There was an extensive discussion on their political objectives and actions, particularly around the organization of solidarity and community mobilization events. The activist/participant observations were accompanied by numerous 'informal conversational interviews' (Patton, 2002, p. 342), and were all recorded as fieldnotes (155 pages). We also conducted twelve semi-structured interviews (14.5 hours) face-to-face and through video conferencing - with members of the two SIs that lasted between one to two hours and were tape-recorded with the consent of the participants. In addition, we conducted two group discussions (3.5 hours) with members of the WCNA and the Workers' Clinic. Finally, documentary sources such as pamphlets, posters and leaflets released by the two SIs as well as websites, blogs and film documentaries assisted in the interpretation of interview transcripts and fieldnotes. 
Data Analysis: In the very early stages of the analysis, we acknowledged that solidarity events, regularly performed across various contexts, play a key role in the constitution and evolution of SIs. Solidarity events are actions that constitute a web of interconnectivities, which holds together emerging structures of resistance, creates patterns of actions, and affirms a process of becoming (Whitehead, 2004). These actions mobilize wider communities around a specific objective and enact relational ties among activists. In our analysis, reflecting on the relationship between present, past and future, we organized our data as a cluster of events (Cobb, 2007; Hernes, 2014), and sought to unveil the practices through which SIs enact organizing practices with new resistance potentialities.

We focused specifically on two dimensions of an events-based framework as proposed by Hussenot \& Missonier (2016): a) the actual event as unit of analysis to understand organization and b) how past and future events are embedded in the actual event. In stage 1, we identified three types of events namely, the General Assembly Meetings (regularly held by both initiatives), the spontaneous encounters and/or workshops (held in autonomous spaces, like squats) and finally, what we refer to as the 'Caravans', mobilizations organized by various collectivities and autonomous groups. In stage 2, through an iterative process between theory and empirical work, we focused on the evolution of events and their role in the constitution of SIs and spatial processes of organizing. Stressing the socio-spatial and temporal dimensions of an event, we organized both fieldnotes and transcribed interviews per where, when and how specific events evolved in relation to other events. Doing this, we traced the flows of knowledge, experiences, resources and actors across spaces and coded the empirical material according to whether a practice unfolded within a (temporarily) fixed space - 'local' - or if it was co-constituted through the movement of agencies 
across space and time - 'translocal'. In the final stage of the analysis, representing these two analytical categories, three distinct local and three translocal organizing practices were identified, which are discussed in detail in the section that follows. Despite treating them as separate analytical categories, we note here that 'the local' and 'the translocal' are not isolated but remain interrelated during the enactment of solidarity events (see Figure 2 below for a summary of the stages of the analysis).

Insert Figure 2 about here

\section{Findings: The Organizing Practices of Solidarity Initiatives}

In this section, we first discuss three local organizing practices as identified in our data: the general assembly meetings of SIs, the co-production of what we term 'resistance laboratories' for experimentation, and the (re)articulation of socio-spatial relations. After that, we turn our attention to the ability of SIs to evolve due to their capacity to connect with other spaces and mobilize seemingly unrelated communities towards the enactment of translocal resistance socio-spatialities. We propose three translocal practices, which describe what we see as solidarity-in-motion, namely, the organization and participation in solidarity mobilizations, the material and symbolic co-production of resources (solidarity fund) and members' mobility. Figure 3 presents an overview of the findings discussed in detail below.

Insert Figure 3 about here

\section{The local organizing practices of Solidarity Initiatives}

General Assembly Meetings: As participants stressed, SIs are part of their efforts to create spaces that "would not only deal with the problem of unemployment but also 
operate as a space for prefigurative politics, where people have the opportunity to put their ideas in practice and at the same time disseminate and circulate these political ideas and practices to the wider public' (Fieldnotes, Informal conversational interview, WCNA, 2013). In order to achieve this, SIs are trying to nurture local organizational practices where

'the basic characteristics of a capitalist organization can be challenged. They are also a form of a collective struggle with high political commitment and collective responsibility that seek to create, here and now, a different form of organizing' (Fieldnotes, Informal conversational interview, WCNA, 2013).

One such practice is the general assembly meetings, regularly organized by both SIs. The general assembly meetings (GAMs) enable 'different group representatives and others to come together, exchange and debate ideas and organize collective actions' such as participating in general strikes, help Vio.Me workers to resist eviction or organize festivals in support of other initiatives and 'spread the idea of cooperativism and workers' struggle' (Fieldnotes, participant observations of GAMs, WCNA, 2014). Similar to the case of WCNA, the spokesperson of Vio.Me.SI highlighted the role of GAMs in opening up their SI to the wider public and mobilizing collective action. In their own words,

'Collective action and wider public mobilization for the Vio.Me factory, for example the organization of the 'Caravan for Struggle and Solidarity' and other activist events and various protests, could not be achieved without the support of the various solidarity members in both material and organizational terms $[\ldots]$. These actions are all decided during the General Assembly Meetings' (Interview, Vio.Me.SI, 2015). 
During the assembly meetings, while they maintain their autonomy, different groups and individual activists participate in an open process of deliberation to promote the SI's collective interests. As a member of WCNA explained, 'the decision-making process during the general assembly is the most important aspect of deliberation and a necessary tool for creating a truly democratic and autonomous space' (Interviews, WCNA, 2014). The representative of each cooperative is trying to establish effective communication with other SI members and their responsibilities are strictly of a coordinating nature, as 'all decisions have to be approved by the general assembly of the cooperative group they represent' (Fieldnotes, participant observations of GAMs, WCNA, 2014). Moreover, 'every cooperative can act independently and participate in any political or other activity as they see fit, yet in order to participate in an extrovert activity as representatives of the WCNA, all cooperatives, members of WCNA, have to reach consensus during the GAMs of the SI' (Fieldnotes, Informal conversational interviews, WCNA, 2014). This is due to the SI members' intention to create the conditions for non-hierarchical and inclusive processes that will allow participating alternatives to work together as autonomous entities.

Inevitably, on some occasions, points of disagreement may arise upon which members are encouraged to collectively reflect. Rather than searching for a conflictfree assembly, they highlighted that the challenge to achieve a truly democratic initiative is to remain open and receptive to the other. They also emphasized the importance of dealing with conflicts by considering 'the reasons that lead to disagreements and reaching a decision that would satisfy everyone involved' (Fieldnotes, Informal conversational interviews, WCNA, 2014). In this sense, GAMs 
also function as a 'shared space for self-exploration, transformation, dignity and respect' (Interviews, Vio.Me.SI, 2014). The process of dealing with conflict and reaching consensus indexes the establishment of a relationship through which members gradually learn to work together, listen to others and become receptive to new ideas. For example, a WCNA member (from Syn.all.ois) referred to the assembly meetings as the 'big school' where 'you change as a person'. On the same issue, another WCNA member (from Pagkaki) pointed to the cultivation of a consciousness of self-reliance, receptiveness and openness ${ }^{4}$. Talking about her own experience, she explained:

'You have to be receptive to new ideas, and be able to make compromises [...] it is not about my opinion or your opinion; it is about the whole group. I think that the assembly creates the grounds to somehow control our excessive ego and I believe that we have all changed through these collective processes' (Group discussion, WCNA, 2012).

Co-Constitution of 'resistance laboratories': As members of WCNA explained, 'other collectivities and individuals who either want to share experiences or wish to join the initiative regularly attend meetings and participate in various seminars and workshops organized either in the spaces of the WCNA cooperatives or in other social spaces' (Fieldnotes, Informal conversational interviews, WCNA, 2014). A similar practice is evident in the case of Vio.Me.SI where workshops, seminars and social events (such as concerts) are organized either in the premises of the Vio.Me factory or in other fixed, local sites, such as the social space of Micropolis, or the occupied building of Scholio. During these encounters, participants share experiences and knowledge and ultimately develop and expand a network of alternative organizations 
by encouraging others to participate in various political actions and get actively involved with self-organized spaces and resistance movements. Thus, by fostering engagement and inclusive participation, local sites are transformed into what we refer to here as resistance laboratories. That is, they become transient, meaningful places of resistance and experimentation (Courpasson et al., 2017; Shortt, 2015; Tuan, 1977), which temporarily (and often, spontaneously) fix movements and flows of entities, providing the material conditions through which existing and new members consolidate and diffuse knowledge as well as share views and ideas. For example,

'in September 2014, several workers from Vio.Me factory and Vio.Me.SI members gathered at Micropolis to hold the regular general assembly meeting of the initiative. On the same day, Cooperativa Integral Catalana (CIC), a cooperative from Catalonia, visited the social space of Micropolis and run a workshop on cooperative practices, that was attended by various selforganized collectives. Naturally, Vio.Me.SI members also joined the discussions' (Fieldnotes, participant observation, Vio.Me.SI, 2014).

In this workshop, participants shared experiences and knowledge, and co-constituted a resistance laboratory within the space of Micropolis, where possibilities for collaboration, mutual support and alternative organizing were explored. This temporary encounter contributed to the emergence of an unexpected, new formation: the CIC is now directly involved with the Alternative Festival of Solidarity and Collaborative Economy in Greece in which both Vio.Me.SI and WCNA also participate, enhancing the collaboration with several other collectivities and cooperatives. Accordingly, resistance laboratories, organized by SIs in local sites, 
constitute the necessary socio-spatial arrangement through which resisters connect and collective experimentation is enacted.

Moreover, resistance laboratories also become points of reference for those who want to establish their own alternative organizations. As one participant explained: 'You exchange ideas and you start feeling more confident that you can achieve something different too; that something different can actually work out' (Informal conversational interviews, WCNA, 2014). The extent to which resistance laboratories have contributed to the increase in the number of alternative organizations in Greece over the past few years (Enallaktikos, 2015) ${ }^{5}$ may be difficult to assess. However, we argue that resistance laboratories could provide the necessary socio-spatial arrangements for 'scaling across' to take place: a process whereby small efforts grow large not through replication, but by inspiring each other to keep inventing and learning (Wheatley and Frieze, 2011); that is, a process through which people, ideas, knowledge and experiences travel across space and time, and mobilize others to resist and join a translocal experimentation for alternative ways of organizing work and life.

Re-articulation of socio-spatial relations: The ways SIs (re)articulate socio-spatial relations (Featherstone, 2011; Hall, 1980; McFarlane, 2009) and the practices through which they connect with other local struggles were found crucial in the organizing of resistance. In particular, in the cases we studied, we witness the transformation of previously enclosed and privatized spaces (capitalist enclosures) into open, collective and political spaces for building solidarity ties and organizing new resistance sociospatialities. As a member of Vio.Me.SI explained, SIs invite local residents and 
workers to challenge articulations of urban space as exclusively available to them for production and consumption:

'The factory is not just a space of production; it is a space of work and life, an open space for the wider community and, for that reason, various events (open market days, music festivals) are organized on a weekly basis. The factory becomes the city' (Interview, Vio.Me.SI, 2016).

Embracing the open factory or la fábrica abierta, a term that describes the community activities that the recuperated factories in Argentina initiated (Fernández et al., 2016; Vieta, 2010) ${ }^{6}$, the SIs we studied also encouraged the re-use of the spaces they occupy and the (re)articulation of dominant socio-spatial relations by assembling new social, cultural and political socio-spatialities. The new socio-spatial arrangements, that the open factory entails, transform the relationship between citizens, workers, (working) spaces and communities and establish SIs, not as isolated entities but part of entangled socio-spatialities of resistance. The Workers' Clinic is an example of this transformation: it is a new resistance socio-spatial formation that brings together different struggles of self-organization and autonomy. Resistance spaces like the factory of Vio.Me and the social centre of Micropolis have contributed to the emergence of the Clinic, bringing together various mobile socio-spatialities and temporarily 'anchoring' resisters and resistances to a concrete socio-spatial formation, the 'factory-clinic' (Fieldnotes, Group discussion, Workers' Clinic, 2016). Specifically, as a member of the Clinic explained,

'this initiative emerged after four years of independent struggles for selfmanagement and autonomy by health care workers and the workers of Vio.Me and is based on mutual respect of non-hierarchical, unmediated collaboration. 
Both Vio.Me and the Clinic demonstrate that they are open to forming links with other communities and autonomous movements and capable of creating new spaces where people can collaborate and co-produce an alternative social reality. We thus invite everyone not only to support the clinic but also become part of it' (Film documentary, January 2016) ${ }^{7}$.

Hence, the initiative of Vio.Me.SI 'through the prefigurative reconstitution of social relations' (Ince, 2012, p. 1646), facilitated the consolidation of knowledge, resources and experiences. It assembled different socio-spatialities that produced a new resistance space (the Clinic) and actively transformed the resistance potential of the recuperated factory. The 'factory-clinic' formation co-constitutes a multiplicity of socio-spatial relations, such as workers' struggle to take control over their work, the struggle against austerity and unemployment or the struggle for free health care that can enact new modes of resistance in the future. As two doctors/members of the Clinic explained 'the severe cuts had a tremendous impact on the Greek National Health Care system...a growing percentage of the population is unable to afford medical care and treatment in hospitals or other social care facilities' (Fieldnotes, Group discussion, Workers' Clinic, 2016). According to the Organisation for Economic Co-operation and Development (2015), since 2009, per capita spending on public health has been cut by nearly a third - more than $€ 5$ bn. By 2014, public expenditure had fallen to $4.7 \%$ of GDP, from a pre-crisis of $9.9 \%$. In addition, more than 25,000 staff have been laid off and when retired, members of staff are not replaced. 
Clearly, the Workers' Clinic cannot (and does not intend to) act as a substitute or a solution to a poorly functioning public health care system (Fieldnotes, Group discussion, Workers' Clinic, 2016). Social clinics in Greece have indeed significantly contributed to delivering care for the affected communities (Cabot, 2016). Crucially though they also provide open spaces where new social ties can be created. Besides Vio.Me.SI, their struggle is tightly linked to other struggles in Northern Greece (for example, the struggle against water privatization or gold mining in Skouries, two significant resistance movements which regularly organize solidarity events in the wider area of Thessaloniki) and other social clinics and pharmacies across the country. Becoming part of a wider landscape of resistance movements, the Clinic becomes established as a fixed space in the premises of the Vio.Me factory, and by participating in various solidarity mobilizations, co-constitutes new resistance potentialities. Through solidarity, society is reconceived as an active force and framed as both the repository and recipient of care. As part of the Clinic, members also participate in forms of exchange based on horizontal social relationships and mutual reciprocities, rather than asymmetrical obligations. Thus, the Workers' Clinic seeks to contest the hegemonic constructions of privatized, hierarchical or enclosed health care spaces, and engages in an inclusive, open and democratic initiative, both in the ways that the health care provision is organized and relationships between patients and healthcare professionals are managed.

So far, we have focused on the local organizing practices that SIs employ to strengthen both solidarity relations across space and time as well as enhance their potentialities for organizing resistance. We have shown that the regular general assembly meetings constitute spaces of encounter and possibilities, which without 
being amorphous have the capacity to remain open and inclusive, forging strong solidarity ties among members. Second, we proposed that these socio-spatialities, that emerge from intersecting subjectivities become sites for experimentation or resistance laboratories, where individuals and activist groups share and disseminate knowledge, co-constituting what we referred to as resistance laboratories. Finally, we argued that the (re)articulation of social-spatial relations gives rise to new spaces for political agency where different resistance trajectories come together to co-produce alternatives. In the analysis that follows, we propose that fixities are only temporary, always in interplay with mobile agencies that encourage translocal organizing.

\section{The Translocal Organizing Practices of Solidarity Initiatives}

Expanding the discussion on SIs' organizing practices, in this section, we will argue that the potential of SIs to resist capitalist socio-spatial arrangements (such as hierarchical organizational structures, neoliberal urbanism, privatization of public services and land), is critically based on their capacity to (dis)connect from/to other activist spaces and co-produce translocal organizing practices. Three distinctive translocal practices emerged from our study and are discussed below.

Solidarity Mobilizations: Although some of the SIs' activities remain localized (emerge and evolve within fixed spaces), solidarity practices cannot be fully divorced from social interactions that take place in and through much larger spatial scales. As Harvey (1989) put it, the choice of scale in political activism is not 'either/or' but 'both/and'. Vio.Me.SI members stressed that the event that was crucial in the establishment of their self-organization initiative was the Caravan for Struggle and Solidarity, a translocal solidarity mobilization that initially launched the SI in 
Thessaloniki (where Vio.Me is situated) and, by travelling around Greece, communicated the recuperated factory's cause around the country. Reflecting on the success of this mobilization, a worker from the Vio.Me factory described:

'[...] the Caravan was the start of it all [...]. We are very pleased with how many people participated considering that we also had to occupy the premises of the factory at the same time and organize other activities too' (Interview, Vio.Me.SI, at Micropolis, 2013).

This Caravan, largely initiated by the Vio.Me.SI, gradually evolved to include other autonomous collectives that responded to the call for the creation of a common, nonhierarchical resistance front. A press release (April, 2015) clearly affirmed: 'The Caravan for Struggle and Solidarity is and will always remain a space for autonomous, non-hierarchical struggles; open to labor and social struggles, neighborhood assemblies, social movements and collectives, workers and unemployed $^{9}$. This initiative created a mass mobilization of autonomous and antiauthoritarian groups across the country such as the self-organized initiatives of the Greek broadcaster ERT3, the social centre of Micropolis and several residents' activist groups like the Solidarity Network Exarcheia (see Figure 1). Vio.Me.SI has also expanded internationally, as solidarity committees have already been organized in the US, Argentina, Australia, Vienna, Copenhagen, Poland and the UK. In June 2016, another Caravan was organized: Participants began their mobilizations in Thessaloniki and eventually arrived in Athens, to challenge the inactivity of the government and its unwillingness to legalize the operation of Vio.Me. A great number of solidarity members and activists around the country participated in both the first Athens meeting of the Caravan at the occupied theatre Embros, as well as the protest 
camp that was organized outside the Greek Ministry for Employment, which lasted several days (Fieldnotes, Activist/Participant Observations, June 2016).

Solidarity mobilizations, such as the Vio.Me.SI Caravans, become spaces for organizing resistance. Through translocal mobilization, SIs take their struggle to different self-organized spaces (organizing events in spaces like the occupied theatre Embros, the squat of Scholio or the social center of Micropolis), and become entangled with other struggles, expanding the socio-spatial boundaries of their activity. Therefore, along with resistance laboratories, which are regularly coconstituted within fixed, local sites and temporarily fix the movement of (non-) human actors, solidarity mobilizations unfold across space and time and assemble diverse, translocal subjectivities, which otherwise may have remained disconnected.

Symbolic and material co-production of resources: The solidarity fund, initiated at the WCNA, constitutes another translocal organizing practice, which aims to strengthen local political actions and reinforce translocal solidarity. The fund was first introduced at Pagkaki cooperative to support a range of heterogeneous struggles of newly established cooperatives (such as the Kivotio cooperative in Crete) and workers' strikes (as in the cases of ACS courier and the steel workers of Halyvourgiki). As members explained,

'during general strikes, we keep the cooperative closed in order to participate in the protest and when it is over, we open the cafe and any money we make goes to the strike-solidarity fund [...] For us, this act of solidarity has both a symbolic and material dimension and helps us connect with other workers' struggles in Greece' (Fieldnotes, Informal conversational interviews, Pagkaki, 2015). 
The idea of solidarity funds was then adopted in the WCNA in order to provide support to cooperatives and other alternative organizations within the SI and workers' struggle across the country. The solidarity fund is supported by: a) monthly contributions by all permanent members of the WCNA; b) solidarity events organized by WCNA and c) raising the price of a pre-selected item (chosen by the cooperatives), noting to customers that the price premium is their contribution to the fund. Since there are no specific criteria or guidelines as to how to distribute these funds, funding decisions are made at the regular GAMs of the WCNA. The support provided is nonreturnable, while decisions on eligibility are based upon the principles, values and characteristics of the groups as well as the nature of their struggles (e.g. providing financial support to workers during strikes).

The establishment of the solidarity fund demonstrates the realization that resources have to be produced and shared across fixed spaces. Thus, the resources that the SI consolidates locally are distributed to different resisting spaces (translocally), enabling other resisting spaces to organize differently and create alternatives to the dominant established arrangements (for example, financial support via solidarity funds instead of bank loans). Therefore, by instituting practices of translocal organizing, resistance formations become productive forces that evolve through the constant reconfiguration of resources, and challenge existing socio-spatialities by offering new ways for organizing (working) relationships. A symbolic and material practice, like instituting the solidarity fund, becomes a creative force that opens up a new realm of social possibilities. 
Members' Mobility Scheme: The scheme began as an act of solidarity between members of the WCNA to support one of the cooperative groups in the initiative to deal with an unexpected member shortage and gradually became a regular practice. As one of the participants explained, 'under this scheme, members of the WCNA have the opportunity to participate and work simultaneously in more than one cooperatives, move temporarily or even transfer to another cooperative on a more permanent basis' (Fieldnotes, Informal conversational interview, WCNA, 2016). He explained that there is an ad hoc process of moving from one site to another and is based on the task-related needs of the cooperatives in the WCNA. First, the cooperative will request extra members from the SI and provide information about the period these member(s) are needed for, the remuneration scheme and any other rolerelated rights and responsibilities (the same as permanent members). Then, members declare their interest. The same process is followed if individual members request to move to another group (either temporarily, jointly or permanently). In all cases an agreement from all parties involved is required (Fieldnotes, Informal conversational interview, WCNA, 2016).

Through the mobility scheme, therefore, members can experience work processes in other sites, collaborate outside the dominant structures of social and economic exchange, diffuse knowledge and resources and gradually develop collective tools for building alternative modes of work and cooperation. Thus, the members' mobility scheme, the organization of solidarity events, and the initiative of solidarity funds coconstitute a creative resistance process, a bridge that connects local spaces, and consolidates and diffuses resources for exploring ways of organizing and resisting differently. This movement plays a significant role in crafting strong links across the SIs, and highlights the importance of translocal cooperation in the production of 
forms of resistance that are not temporary acts of political contestation, but a collective effort with transformative potentialities.

\section{Discussion}

The attempt to develop new socio-spatial relations is conducted as a strategy of solidarity through which the enduring contestation of capitalist social spaces (such as the factory as a space of domination, subjugation and control) brings about new spaces of resistance and new social relations. By actively engaging with political activity, SIs transform what we traditionally understand as 'the workplace', and invite others (not directly involved with the factory, like members from the Social Clinic of Solidarity in Thessaloniki) to participate in the organization and evolution of alternative organizations within fixed, local spaces (for example, the establishment of the Workers' Clinic in the premises of Vio.Me). This is crucial for understanding the potential impact of space-based solidarity practices in the production of resistance and alternative organizing. Yet, by also accounting for translocal enactments and reenactments of solidarity, this study also unveils the practices through which transformative potentialities in the organizing of resistance could emerge.

In particular, the contribution of this paper is threefold. First, we contribute to the literature that stresses that resistance should be studied in relation to where things happen (Courpasson \& Vallas, 2016; Polletta, 1999; Juris, 2008). Focusing on 'the spatial constitution of political activity' (Featherstone, 2011, p. 142), we turned to the articulatory socio-spatial practices through which new sites of resistance are constituted. Expanding the discussion on resisting places as actual, meaningful settings (Courpasson et al., 2017) or 'transitory dwelling places' (Shortt, 2015), we 
suggest that resistances are also dispersed across spaces and times. In particular, the constant interplay between staying local and becoming translocal enables the differential inhabitation of spaces where various groups and individual agents meet; a process of multiple crossings of the known frontiers towards 'new forms of collective self-determination' (Stavrides, 2010, p. 13). Accordingly, resistance formations create socialities that are not attached to concrete spaces/places; rather, new resistance potentialities emerge through the constant flows of actors: a complex movement by which something escapes or departs from a given territory (Deleuze \& Guattari, 1987), when articulations are disarticulated (Slack \& Wise, 2005) and then rearticulated or re-territorialized; except this time, the act of re-doing brings along transformed relationalities.

Second, we propose that resistance is a multi-faceted, transformative everyday practice through which individuals and collectives, challenge symbolic, material and immaterial boundaries, perform transgressions and inversions, collapse binaries and capture the increasingly complicated nature of socio-spatial processes and agencies. Accordingly, solidarity and resistance should not be explored as separate processes with one doing something to the other. Instead, the ongoing entanglements of actors, resistances and (trans)local practices continuously (re)assemble what Marti and Fernández (2013, p. 1197) described as 'spaces for agency'. These entangled spaces establish SIs as sites for economic and political experimentation and alternative organizing, and demonstrate that fixed and mobile agencies can co-constitute new socio-spatialities for organizing resistance. The ongoing reconfiguration of new sociospatialities shifts the boundaries of the way in which space is produced, giving way to what Lefebvre (1991) calls 'differentiated space', whereby the different needs of the 
community determine the way in which space is conceived and used. For example, the Workers' Clinic is a new self-organized initiative, an alternative space (a medical centre situated in an occupied factory) that operates in, and evolves together with another alternative space (the factory of Vio.Me), part of the ongoing process of (re)assembling new solidarity relations. Although this initiative has just begun and the processes of its evolution are still to be determined, the Clinic is clearly an illustration that SIs foster new spaces for political agency and can assemble diverse trajectories of resistance towards transformative collaborative actions. Thus, the emergence of entangled spaces of agency, a creative and transformative practice, demonstrates how resistance produces alternatives and highlights the ever-present possibility of (re)arranging spaces in ways that foster conditions for new resistance formations to emerge.

Third, we propose that resistance constitutes and is constituted by complex relations of solidarity. In particular, we draw attention to the distributed and fluid socio-spatial resistance configurations, and suggest that resistance is a creative process that shapes political subjectivities and can bring about social transformation (Bloom, 2016). By embracing both temporary fixities (for example, the constitution of resistance laboratories in local spaces) and mobilities (for example, instituting members' mobility schemes), SIs constitute resistance formations that consolidate resources, experiences and knowledge while at the same time, establish bridges across spatial scales that are proven critical for diffusing a repertoire of local and translocal organizing practices. Thus, our study supports previous work that emphasizes the importance of various political processes and tactics through which resistance formations become embedded into wider societal practices, disrupting and re- 
organizing dominant yet ineffective social and institutional arrangements (Daskalaki, Hjorth, \& Mair, 2015).

Nevertheless, we are mindful of the political and institutional forces, which threaten the sustainability and expansion of these initiatives and acknowledge that the two SIs we studied, like other grassroots initiatives, are subject to boundary conditions that affect the ways they organize and can limit their activities and potentialities. Resistance socio-spatial formations are both enabled and constrained by economic, political, social and cultural settings and situations in which they are embedded (Böhm, Dinerstein, \& Spicer, 2010), and which in this instance, are penetrated and deeply affected by the crisis of neoliberal capitalism. These formations must resist fatigue, attempts of appropriation, and counter-movements that want 'to maintain the status quo or retreat to an imagined idealized past' (Flesher Fominaya, 2017, p. 16). In addition, state responses to social movements are increasingly characterized by measures that seek to confine the expression of resistance (Butler, 2015). These responses range from a surge in repression policies, to significant new constraints on the freedom of assembly and the exercise of civil liberties (Hayes, 2017). For example, Amnesty International (2012) described the excessive use of force by the Greek police during protests as 'repeated' and 'routine'. Also, the factory of Vio.Me is under the constant threat of eviction, as the government refuses to legislate in favour of worker-recuperated businesses and endorses the auction of the Vio.Me premises. Despite this hostile environment, resisters through local and translocal organization-creation, institute new sites of resistance, which create possibilities for envisioning and practicing workable alternatives to the present realm of organizing. These sites of resistance encourage creative collaborations and interventionary 
political action and demonstrate the importance of embedding situated instances of resistance in translocal solidarity movements that mobilize collective action. Resistance transforms and is transformed through the constant reconfiguration of socio-spatialities, a historical process that 'opens up the way for moving from a history of permanent revolution to one of eternal possibility' (Bloom, 2016, p.13).

To sum up, our analysis of the two SIs adds to the emergent literature on space/place and resistance by providing support to research that advocates a departure from a binary, instrumental and reductive understanding of resistance (Checchi, 2015), and from a neutral, static and fixed understanding of space (Munro \& Jordan, 2013; Shortt, 2015; Taylor \& Spicer, 2007). By contributing to a spatial conceptualization of resistance (Courpasson et al., 2017, Courpasson \& Vallas, 2016; Fernandez et al., 2016), we affirm its complexity as being not only an (un)intentional and (un)anticipated act of refusal but also a transformational process of becoming within and across spaces/places. Resistance evolves as a constant reconfiguration of sociospatial formations, a productive process that 'shapes ideas of politics and the potential for social transformation' (Bloom, 2016, p. 6). Offering a more creative and productive understanding of resistance, we propose that if resistance is a spatial practice, and space is itself not fixed but always in the making, then resistance can be constitutive of new possibilities, a productive encounter between differences that can offer glimpses into worlds 'yet to come' (Deleuze, 1990, p. 175-6).

\section{Concluding remarks and future research}

In this paper, we suggested that SIs consolidate and diffuse experiences, resources and knowledge through distinctive local (GAMs, resistance laboratories and re- 
articulation of spatial relations) and translocal organizing practices (solidarity mobilizations, the material and symbolic co-production of resistance resources and mobility of agents). By staying fixed as well as becoming mobile, SIs embrace the importance of localized, space-bound actions while at the same time also build collaborative engagements with different others for the expansion of resistance spaces to other spaces, other topoi, other subjectivities.

Although SIs affect the emergence of alternative spaces of resistance, they still operate within neoliberal urban, cultural and socio-economic spheres. This makes every resistance formation fragile, however, 'not in the sense that it is already formed and might be easily broken but in the sense that it is taking shape and needs care and caution as it comes into being' (Gibson-Graham, Cameron, \& Healy, 2014, p. 1062). Without providing an overly positive and conflict-free account of alternatives and SIs, we recognize that resistance is a process of struggle, negotiation and constant transformation. Undoubtedly, forces of subjugation attempt to orchestrate the 'fencing' of new resistance territories in order to appropriate their function, fragment their struggles and minimize their translocal potential and effect. Future research, therefore, could explore first the conflicts arising as part of the consolidation and diffusion of alternative practices on both local and translocal levels and second, the defensive practices that resistance formations institute to maintain their socially transformative potentialities.

Moreover, while we consider the co-constitution of new spaces a crucial factor for the establishment of SIs, we have no intention to suggest that spatiality and/or mobility alone affect resistance possibilities. We acknowledge the politically contested nature 
of mobilities (Braidotti, 1994; Cresswell, 2002; Urry, 2007) and the ways in which this affects resistance potentialities. Indeed 'mobility and control over mobility both reflect and reinforce power. Mobility is a resource to which not everyone has an equal relationship' (Skeggs, 2004, p. 49). Yet, it is not a question of favoring a 'mobile subjectivity', but rather of 'tracking the power and politics of discourses and practices of mobility in creating both movement and stasis' (Hannam et al., 2006, p. 4). Consequently, future studies could expand this work by also exploring how mobilities are mediated by a combination of other factors such as organizational objectives and collective values within and across spaces.

To conclude, drawing on the analysis of the local and translocal organizing practices of two solidarity initiatives, this paper provided a spatial conceptualization of resistance. We proposed that the institution of a resistance milieu is linked with constantly changing socio-spatial relations, which become enacted through local and translocal experimentation, evolution and transformation. Resistance is a collective and spatially performed act of creation, a continuous reconfiguration of socio-spatial relations that can bring about new forms of political agency and transform the ways we work and organize.

\section{Acknowledgements}

We would like to thank all participants of the WCNA, the Vio.Me.SI and other selforganized spaces, for agreeing to contribute to this study and for being a continuous source of inspiration to us while writing this article. Special thanks also to Valerie Fournier and Orestis Varkarolis for their constructive feedback in early versions of this work, and to Ioanna Ferra, for helping us with the visual representation of the two initiatives (Figure 1). Last but not least, we are grateful to the editors of the Special Issue, Ignasi Martí, Dennis Mumby, David Seidl and Robyn Thomas, the Editor-in- 
Chief, Frank den Hond, and the three anonymous reviewers for their constructive comments and insightful suggestions throughout the review process.

\section{References}

Adey, P. (2010). Mobility. London: Routledge.

Adey, P., Bissell, D., Hannam, K., Merriman, P., \& Sheller, M. (2014). The Routledge handbook of mobilities. London: Routledge.

Alcidi, C., Giovannini, A., \& Gros, D. (2011). History repeating itself: from the Argentine default to the Greek tragedy? CEPS commentary, July.

Allen, J. (2011). Topological twists: Power's shifting geographies. Dialogues in Human Geography, 1, 283-298

Amnesty International (2012). Police Violence in Greece: Not just 'isolated incidents'. London: Peter Benenson House.

Anderson, B., Kearnes, M., McFarlane, C., \& Swanton, D. (2012). On assemblages and geography. Dialogues in Human Geography, 2, 171-189.

Arampatzi, A. (2016). The spatiality of counter-austerity politics in Athens, Greece: Emergent 'urban solidarity spaces'. Urban Studies. Epub ahead of print 3 February 2016, DOI: 10.1177/0042098016629311.

Baerenholdt, J. O. (2013). Governmobility: The powers of mobility. Mobilities, 8, 2034.

Bohm, S., Dinerstein, A.C. \& Spicer, A. (2010). (Im)possibilities of autonomy: social movements in and beyond capital, the state and development. Social Movement Studies, 9, 17-32.

Bloom, P. (2016). Beyond power and resistance: Politics at the radical limits. London: Rowman \& Littlefield International.

Braidottti, R. (1994). Nomadic subjects: Embodiment and sexual difference in contemporary feminist theory. New York: Columbia University Press.

Brenner, N., \& Elden, S. (2009). Henri Lefebvre on state, space and territory. International Political Sociology, 3, 353-377.

Butler, J. (2015). Notes toward a performative theory of assembly. Cambridge: Harvard University Press.

Cabot, H. (2016). 'Contagious' solidarity: reconfiguring care and citizenship in Greece's social clinics. Social Anthropology, 24, 152-166. 
Chatterton, P., Hodkinson, S., \& Pickerill, J. (2010). Beyond scholar activism: Making strategic interventions inside and outside the neoliberal university, ACME, 9, 245-275.

Checchi, M. (2015). Engaging with Foucault's microphysics of power through the primacy of resistance. In A. Zaharijevic, I. Cvejić, \& M. Losoncz (Eds.), Engaging Foucault (vol. 1) (pp. 96-111). Belgrade: Institute for Philosophy and Social Theory.

Christopoulou, R., \& Monastiriotis, V. (2016) Public-private wage duality during the Greek crisis. Oxford Economic Papers, 68, 174-196.

Cobb, J.B. (2007). Person-in-community: Whiteheadian insights into community and institution. Organization Studies, 28, 567-588.

Courpasson, D., Dany, F., \& Delbridge, R. (2017). Politics of place: The meaningfulness of resisting places. Human Relations, 70, 237-259.

Courpasson, D., \& Vallas, S. (2016). The SAGE Handbook of Resistance. London: Sage.

Cresswell, T. (2002). Introduction: theorizing place. In G. Verstraete, \& T. Cresswell (Eds.), Mobilizing place, placing mobility (pp. 11-32). Amsterdam: Rodopi.

Cresswell, T. (2006). On the move: Mobility in the modern Western world. London: Routledge.

Daskalaki, M. (in press). Alternative organizing in times of crisis: Resistance assemblages and socio-spatial solidarity. European Urban and Regional Studies.

Daskalaki, M. (2014). Mobility in urban social events: Towards organizational transvergence. Culture and Organization, 20, 215-231.

Daskalaki, M., Hjorth, D., \& Mair, J. (2015). Are entrepreneurship, communities, and social transformation related? Journal of Management Inquiry, 24, 419-423.

DeLanda, M. (2006). A new philosophy of society: Assemblage theory and social complexity. London: Continuum.

Della Porta, D., \& Mattoni, A. (2014). Spreading protest: Social Movements in times of crisis. Colchester: ECPR press.

Deleuze, G., \& Guattari, F. (1987). A thousand plateaus: Capitalism and schizophrenia. London: Athlone.

Deleuze, G. (1990). The logic of sense. New York: Columbia University Press. 
Dhaliwal, P. (2012). Public squares and resistance: The politics of space in the Indignados movement. Interface: a Journal for and about social movement, 4, 251-273.

Diani, M., \& Kousis, M. (2014). The duality of claims and events: The Greek campaign against the Troika's memoranda and austerity, 2010-2012. Mobilization: An International Quarterly, 19, 387-404.

Featherstone, D. (2008). Resistance, space and political identities: The making of counter-global networks. London: Wiley-Blackwell.

Featherstone, D. (2011). On assemblage and articulation. Area, 43, 139-142.

Fernández, P.D., Marti, I., \& Farchi, T. (2016). Mundane and Everyday Politics for and from the Neighborhood. Organization Studies, 1-23. Epub ahead of print 3 November 2016, DOI: 10.1177/0170840616670438.

Flesher Fominaya, C. (2017). European anti-austerity and pro-democracy protests in the wake of the global financial crisis. Social Movement Studies, 16, 1-20.

Foucault, M. (1984). Space, knowledge and power. In P. Rabinow (Ed.), The Foucault reader (pp. 239-256). London: Penguin Books.

Foucault, M. (1986). Of other spaces (translated by J. Miskowiec). Diacritics, 16, 22 27.

Gibson-Graham, J. K., Cameron, J., \& Healy, S. (2013). Take back the economy: An ethical guide for transforming our communities. Minneapolis: University of Minnesota Press.

Gritzas, G., \& Kavoulakos, K. (2016). Diverse economies and alternative spaces: An overview of approaches and practices. European Urban and Regional Studies, 23, 917-934.

Gustafson, P. (2001). Roots and routes: Exploring the relationship between place attachment and mobility. Environment Behaviours, 33, 667-686.

Graeber, D. (2013). The democracy project: A history, a crisis, a movement. London: Allan Lane.

Hall, S. (1980). Race, articulation and societies structured in dominance. In UNESCO (Ed.), Sociological theories: Race and colonialism (pp. 305-345). Paris: UNESCO.

Hannam, K., Sheller, M., \& Urry, J. (2006). Editorial: Mobilities, immobilities and moorings. Mobilities, 1, 1-22. 
Hardt, M., \& Negri, T. (2012). Declaration. New York: Argo Navis.

Harvey, D. (1989). The condition of Postmodernity. Oxford: Blackwell.

Harvey, D. (2012). Rebel cities: from the right to the city to the urban revolution. Verso Books.

Hayes, G. (2017). Regimes of austerity. Social Movement Studies, 16, 21-35.

Hernes, T. (2014). A process theory of organization. Oxford: Oxford University Press.

Herzfeld, M. (1993). The social production of indifference. Chicago: University of Chicago Press.

Haug, C. (2013). Organizing spaces: Meeting arenas as a social movement infrastructure between organization, network, and institution. Organization Studies, 34, 705-732.

Hussenot, A., \& Missonier, S. (2016). Encompassing stability and novelty in organization studies: An events-based approach. Organization Studies, 37, 523546.

Ince, A. (2012). In the shell of the old: Anarchist geographies of territorialisation. Antipode, 44, 1645-1666.

Jeanes, E., Loacker, B., Śliwa, M., \& Weiskopf, R. (2015). Mobilities in contemporary worlds of work and organising. Ephemera, 15, 705-723.

Jensen, O. (2009). Flows of meaning, cultures of movements - Urban mobility as meaningful everyday life practice. Mobilities, 4, 139-158.

Jensen, O. (2011). Mobility, space and power: On the multiplicities of seeing mobility. Mobilities, 6, 255-271.

Juris, J. (2008) Networking futures: The movement against corporate globalization. Durham, NC: Duke University Press.

Kanellopoulos, K., Kostopoulos, K., Papanikolopoulos, D., \& Rongas, V. (2017). Competing modes of coordination in the Greek anti-austerity campaign, 20102012. Social Movement Studies, 16, 101-118.

Kokkinidis, G. (2015). Spaces of possibilities: workers' self-management in Greece. Organization, 22, 847-871.

Lefebvre, H. (1991). The production of space. Oxford: Blackwell.

Lefebvre, H. (2009). State, space, world: Selected essays. Minnesota: University of Minnesota Press. 
Maeckelbergh, M. (2009). The will of the many: How the alterglobalisation movement is changing the face of democracy. London: Pluto Press.

Maréchal, G., Linstead, S., \& Munro, I. (2011). 'The territorial organization': A special issue of Culture and Organization. Culture and Organization, 17, 449451.

Marti, I., \& Fernández, P. (2013). The institutional work of oppression and resistance: Learning from the Holocaust. Organization Studies, 34, 1195-1223.

Massey, D. (2005). For space. London: Sage.

Matsaganis M. (2013). The Greek crisis: social impact and policy responses. Berlin: Friedrich Ebert Stiftung.

Maxey, L.J. (1999). Beyond boundaries? Activism, academia, reflexivity and research. Area, 31, 199-208.

Maxey, L.J. (2004). Moving beyond from within: Reflexive activism and critical geographies. In D. Fuller, \& R. Kitchin (Eds.) Radical theory/critical praxis: Making a difference beyond the academy? (pp. 159-171). Vernon and Victoria: Praxis Press.

McCann, E.J., \& Ward, K. (2011). Introduction: Urban assemblages: Territories, relations, practices, and power. In E.J. McCann, \& K. Ward (Eds.). Mobile urbanism: Cities and policymaking in the global age (pp. xiii-xxxv). Minneapolis: Minnesota University Press.

McFarlane, C. (2009). Translocal assemblages: space, power and social movement. Geoforum, 40, 561-567.

McMorran, C. (2015). Mobilities amid the production of fixities: Labour in a Japanese inn. Mobilities, 10, 83-99.

Munro, I., \& Jordan, S. (2013). 'Living spaces' at the Edinburgh festival fringe: Spatial tactics and the politics of smooth space. Human Relations, 66, 1497-1525.

Nechio, F. (2010). The Greek crisis: Argentina revisited. FRBSF Economic Letter, 33.

Organisation for Economic Co-operation and Development (2015) Health at a Glance. http://www.oecd.org/health/health-at-a-glance-19991312.htm. Accessed $28^{\text {th }}$ of December 2016.

Pain, R. (2003). Social geography: on action-oriented research. Progress in Human Geography, 27, 649-657. 
Papadopoulos T. (2006). Support for the Unemployed in a Familistic Welfare Regime. In Mossialos E. and Petmesidou M. (Eds.), Social Policy Developments in Greece (pp. 219-238). Aldershot: Ashgate

Parker, M., Cheney, G., Fournier, V., \& Land, C. (2014). The question of organization: A manifesto for alternatives. Ephemera, 14, 623-638.

Patton, M. Q. (2002). Qualitative research and evaluation methods (3rd Ed.). Thousand Oaks, CA: Sage Publications.

Polletta, F. (1999). 'Free spaces' in collective action. Theory and Society, 28, 1-38.

Rakopoulos, T. (2016). Solidarity: the egalitarian tensions of a bridge-concept. Social Anthropology, 24, 142-151.

Rogaly, B. (2015). Disrupting migration stories: Reading life histories through the lens of mobility and fixity. Environment and Planning D: Society and Space, 33, 528-544.

Routledge, P. (1996). The third space as critical engagement. Antipode, 28, 399-419.

Rozakou, K. (2016). Socialities of solidarity: revisiting the gift taboo in times of crises. Social Anthropology, 24, 185-199.

Ruddick, S. (2003). Activist geographies: Building possible worlds. In P. Cloke, P. Grang, \& M. Goodwin (Eds.) Envisioning human geographies (pp. 229-241). London: Arnold.

Rudig, W. and Karyotis, G. (2014). Who protests in Greece? Mass opposition to austerity. British Journal of Political Science, 44, 487-513.

Shortt, H. (2015). Liminality, space and the importance of 'transitory dwelling places' at work. Human Relations, 68, 633-658.

Skeggs, B. (2004). Class, self, culture. London: Routledge.

Slack, J.D., \& Wise, J.M. (2005). Culture and Technology: A primer. New York: Peter Lang Publishing.

Stavrides, S. (2010). Redefining the right to the city: Representations of public space as part of the urban struggles. In G. Sonda, C. Colleta, \& F. Gabbi (Eds.) Urban plots, organizing cities (pp. 35-49). London: Ashgate.

Swyngedouw, E. (2013). 'Every revolution has its square': De-politicization, insurgent architects and the re-emergence of political space. Forum Educatie, Cultuur Samenleving, Universiteit Leuven.

Taylor, S. \& Spicer, A. (2007). Time for space: a narrative review of research on 
organizational spaces. International Journal of Management Reviews, 9, 325346.

Thrift, N. (2008). Non-representational theory: Space, politics, affect. London: Routledge.

Tuan, Y-F. (1977). Space and place: The perspective of experience. Minneapolis: University of Minnesota Press.

Urry, J. (2007). Mobilities. Cambridge: Polity Press.

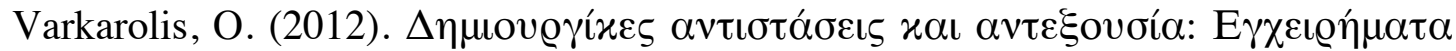

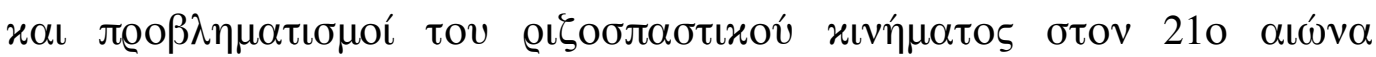
[Creative resistance and anti-power: Initiatives and concerns about the radical movement in the 21st century]. Athens: Pagkaki.

Vasudevan, A. (2015). The autonomous city: Towards a critical geography of occupation. Progress in Human Geography, 39, 316-337.

Vieta, M. (2010). The social innovations of autogestion in Argentina's workerrecuperated enterprises: Cooperatively reorganizing productive life in hard times. Labor Studies Journal, 35, 295-321.

Vogiatzoglou, M. (2015). Workers' transnational networks in times of austerity: Italy and Greece. Transfer-European Review of Labour and Research, 21, 215-228.

Wheatley, M., \& Frieze, D. (2011). Walk out walk on: A learning journey into communities daring to live the future now. California: Berrett-Koehler Publishers.

Whitehead, A.N. (2004). The Concept of Nature. Amherst: Prometheus Books. 


\section{Notes}

${ }^{1}$ In this paper, we use the term 'space' instead of place but we also recognize the interrelationship between the two terms and the long-standing discussions in the literature regarding the kind of relationship that connects the two. The discussion of space, as opposed to place could be seen as one of the markers of modernity, and associated mainly with Newton and Leibniz (Agnew, 2011). For both, neither space nor place can exist without the other. But the priorities differ. For the purposes of this study, we view places as woven together through space by movement and the network ties that produce places as changing constellations of human commitments, capacities, and strategies. Offering a non-Euclidean conceptualization of space, like Massey (2005), we highlight the political implications of practicing space differently. In this approach, both the heterogeneity and multiplicity as dimensions of space are stressed along with the fact that space is never complete but always in the making through interrelations.

${ }^{2}$ These singularities enjoy a certain degree of autonomy in terms of being assigned or reassigned in different assemblages, constituting 'populations of assemblages', a 'multiscalar' social reality (DeLanda, 2006, p. 16).

${ }^{3}$ The status of the 'observer' is given to the cooperative groups of the WCNA on two occasions: a) When they have only recently joined the initiative and have attended less than three meetings; b) When they do not attend the meetings on a regular basis. The main difference from permanent member status is that the observers do not participate in the decision-making process.

${ }^{4}$ For an analysis of these two cooperatives, Pagkaki and Syn.all.ois, see Kokkinidis, 2015 and Varkarolis, 2012.

${ }^{5}$ http://www.enallaktikos.gr/kg15el_diktya-allileggyis.html

${ }^{6}$ Clearly, the 'Greek' and the 'Argentinian' crises are characterized by different financial and socio-economic markers as well the cultural and historical contexts (Alcidi, Giovannini \& Gros, 2011; Nechio, 2010) and comparing the two on those terms goes beyond the purposes of this paper. Our reference to Argentina and the recuperated factories in this paper describes the involvement of Argentinian movements and factories with the factory of Vio.Me and the SIs in Greece (our participants directly referred to this). Examples of this involvement included seminars organized in the factory of Vio.Me. Embracing la fábrica abierta could be considered as evidence that some knowledge from the Argentinian experience has been adapted and transferred across to the Greek cases.

${ }^{7}$ http://webtv.ert.gr/ert3/13ian2015-antidrastirio/

${ }^{8}$ Caravan Press Release (28/04/2015), http://biom-metal.blogspot.co.uk/2015/04/blogpost_28.html 
Figure 1. Map of WCNA and Vio.Me.SI

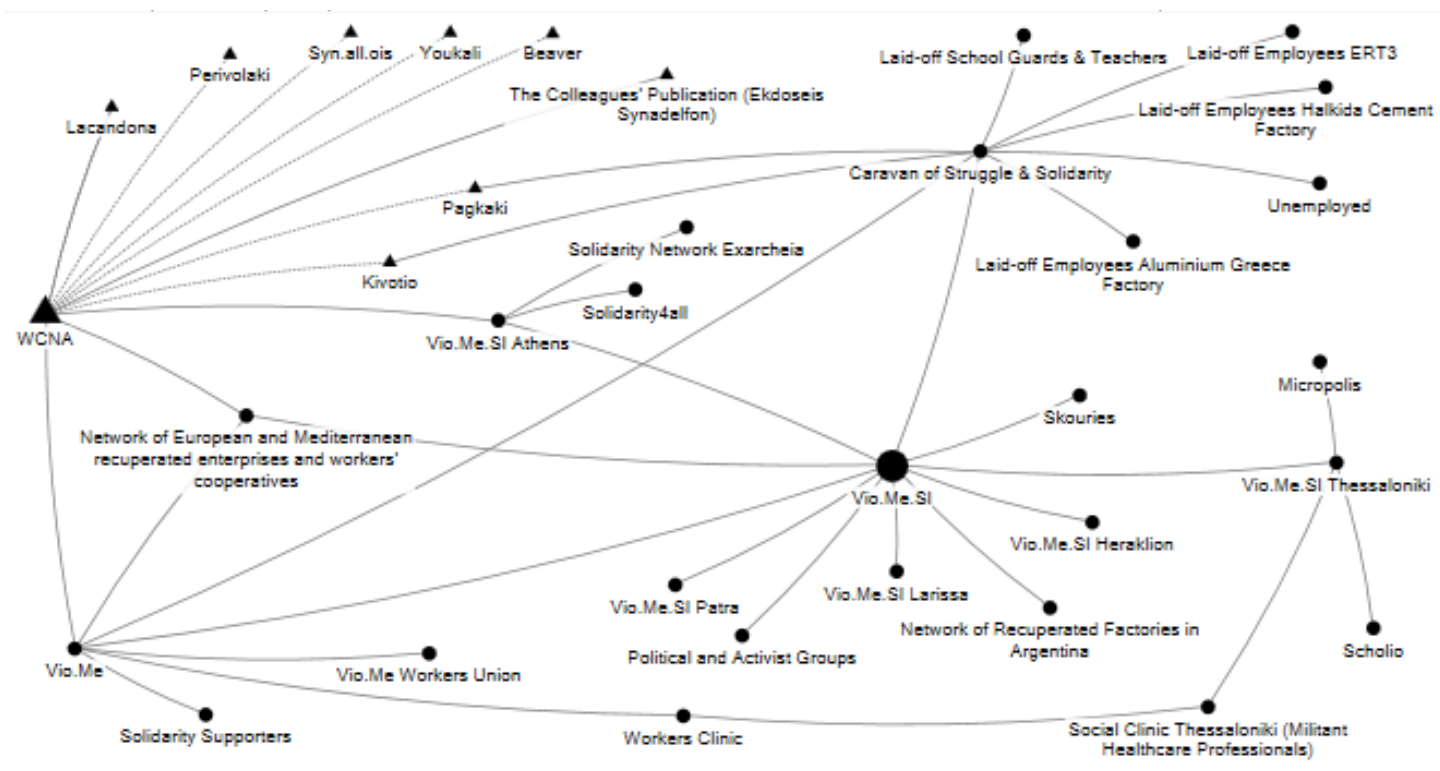

Note: WCNA and Vio.Me.SI are open and fluid social formations and the entirety of their membership cannot be captured. This figure provides a snapshot of the key groups that constitute the initiatives; the WCNA is represented with triangles, while Vio.Me.SI with circles.

Table 1. Data Collection and Data Set

\begin{tabular}{|l|l|}
\hline 12 Semi-structured interviews & 14.5 hours \\
\hline
\end{tabular}




\begin{tabular}{|c|c|}
\hline 2 Group Discussions & 3.5 hours \\
\hline $\begin{array}{l}\quad \text { Participant observations } \\
4 \text { General assembly meetings } \\
2 \text { Festivals (Athens) } \\
2 \text { workshops (Thessaloniki) } \\
\text { Local site visits (Vio.Me factory; Pagkaki, } \\
\text { Syn.all.ois and ERT3) } \\
\text { Informal conversational interviews }\end{array}$ & Fieldnotes (155 pages) \\
\hline $\begin{array}{c}\text { Documentation } \\
\text { (Including digital material) }\end{array}$ & $\begin{array}{l}\text { Posters; Pamphlets; Leaflets; } \\
\text { Websites and blogs; Video } \\
\text { documentary }\end{array}$ \\
\hline
\end{tabular}


Figure 2. Data Analysis: An events-based analytical framework

\section{Stage 1}

The Actual Events

Stage 2

Embedding the

Present in

Past and Future Events

Stage 3

Emerging Themes
General Assembly Meetings

Spontaneous encounters / workshops

The 'Caravans'

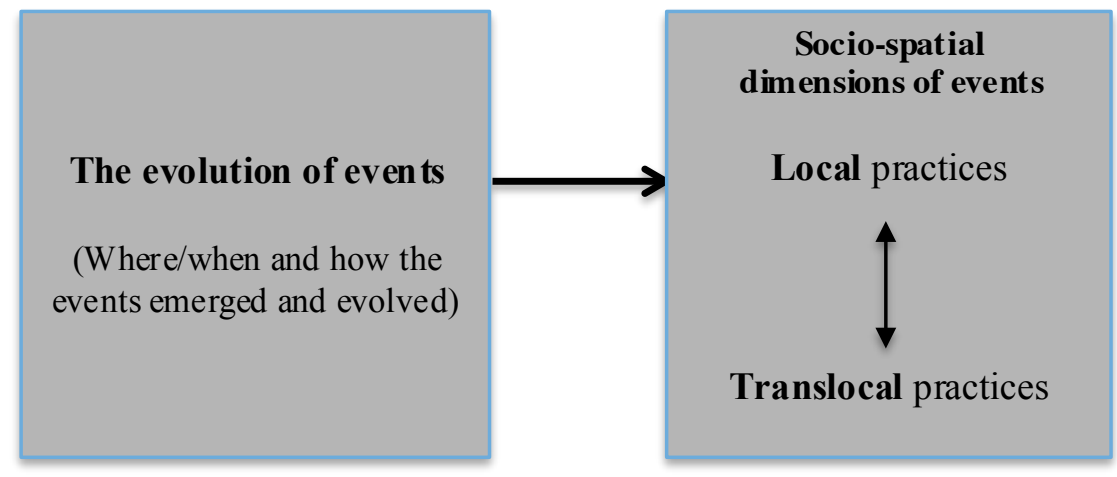

\section{Local Practices}

General assembly meetings

Resistance laboratories

(Re) Articulation of sociospatial relations

\section{Translocal Practices}

Organization of Solidarity mobilizations

Material and symbolic coproduction of resources

Members' mobility 
Figure 3. Organising Solidarity Initiatives: Spaces of Resistance and the fixity-mobility interplay

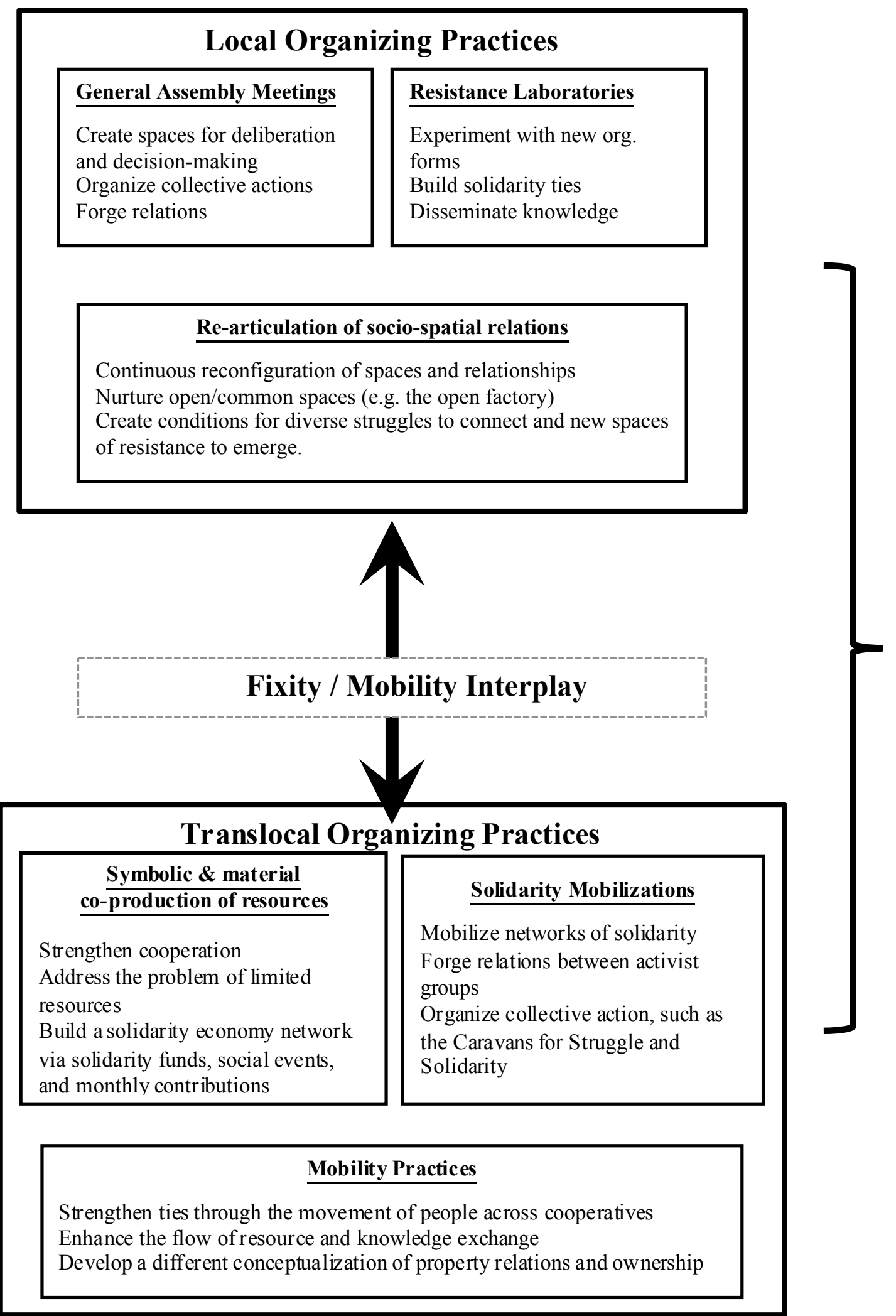


